\title{
Synthesis, of Novel Piperine Analogs of Dipeptidyl Boronic Acid as Antimicrobial and Anticancer Agents
}

\author{
Durvasula V.R. Venugopal ${ }^{1}$, Nagendra Sastry Yarla² and Parimi Umadevi*
}

${ }^{1}$ Department of Chemistry, Institute of Science, GITAM University, Visakhapatanam-530045, Andhra Pradesh, India

${ }^{2}$ Department of Biochemistry/Bioinformatics, School of Life Sciences, Institute of Science, GITAM University, Visakhapatanam-530045, Andhra Pradesh, India

\begin{abstract}
In the present study three piperine analogs of dipeptidyl boronic acid (1 to 3) were synthesized and evaluated the antimicrobial and anticancer activities. Chemical structures of the synthesized compounds were characterized by ${ }^{1} \mathrm{H}$, ${ }^{13} \mathrm{C}$ and mass spectral studies. All the compounds were screened for their antineoplastic activity on HeLa cervical, MCF-7 breast and MIA PaCa-2 pancreatic cancer cell lines and antimicrobial activity against seven bacterial and five fungal species. In vitro results showed that most of the compounds displayed moderate to good inhibitory activity on the tested cancer cell lines, among them compound 1 showed good anticancer activity where as Compound 3 was found to be potent antimicrobial agent against Asperigillus fumigates at a concentration of $62 \mu \mathrm{g} / \mathrm{mL}$ than other tested compounds and the parent molecule piperine. All the compounds were subjected to molecular docking studies on Leucyl-tRNA synthase as well as for $20 \mathrm{~S}$ proteasome inhibition. In silico molecular docking results demonstrated that all compounds had low binding energy toward the active pocket and thus they may act as a good Leucyl-tRNA synthase inhibitor.
\end{abstract}

Keywords: Piperine; Piperic acid; Boronic acids; Anticancer activity; Antibacterial activity

\section{Introduction}

Boronic acids have been illustrious in the literature back in 1860 [1], developing over the years into a wide studied area of chemistry. After the approval of Velcade ${ }^{\star}$ as proteasome inhibitor, boronic acids have emerged as a unique lead for several malignant tumors, as $\beta$-lactamase inhibitors, NS3 protease inhibitors, amino-acyl tRNA synthase inhibitors, and anticoagulants. Boronic acids and its derivatives have gained outstanding importance as a result of their wide-spread biological activity and their use in synthetic chemistry. Piperine, alkaloid from Piper nigrum $L$ found to display an ample spectrum of pharmacologic activities, together with antimicrobial [2] and antineoplastic properties $[3,4]$. Despite the acclaimed potential of piperine, up to now there are few reports available for piperine based antimicrobial and antineoplastic agents. Recent development of conjugate molecules between natural products and synthetic molecules emerged as a new approach in the discovery of novel bioactive agents. Piperine amides or piperine ester analogs were potential cytotoxic agents against different neoplastic cell lines than the parent compound piperine. The activity of piperine lies mostly within the amide linkage [5]. Piperine enhances bioavailablity of drugs [6]; this prompted us to synthesize piperine derivatives of dipeptidyl boronic acid. Encouraged from our antecedent research, we wish to further exploit amide linkage of piperine to get a better antineoplastic and antimicrobial agent.

In modern drug designing, molecular docking is commonly acclimated for understanding drug-receptor interaction. Onychomycosis is a fungal infection of toenails and fingernails that still remains tough to treat. It is acquired primarily by dermatophytes, a category of fungus that dwells on skin, hair, and nails [7]. There are few treatments accessible, and thus they have poor clinical affectivity and lot of safety considerations [8]. The enzyme, particularly LeucyltRNA synthase, is a new target for antifungal. Leucyl-tRNA synthase is a cytoplasmatic enzyme; activate the ATP-dependent ligation of L-leucine to tRNA (Leu). Boronic acid activity on Asperigillus fumigatus is explained by inhibition of active sites in Leucyl-tRNA synthase inhibiting mechanism. All the compounds were subjected to molecular docking studies for Leucyl-tRNA synthase inhibition. In order to find out the effect of conjugated double bond present in piperine for its biological activity, we synthesized the tetrahydro and tetrabromo piperine analogs of peptidyl boronic acid. We achieved to a conclusion that increase in number of halogen atoms accrued antifungal activity on Asperigillus fumigates. Hydrogenation of double bond in piperine lowered anticancer activity. Piperine-boronic acid conjugate has higher antineoplastic activity than the parent molecule piperine and could be a promising lead $[9,10]$.

\section{Experimental}

\section{Chemistry}

General: Commercially available reagents were used directly without any purification unless otherwise stated. Reaction progress was monitored by silica gel aluminum sheets (60F-254) and RP18 F254s using UV light as a visualizing agent and 15\% ethanolic phosphomolybdic acid and heat or ninhydrin and heat as developing agent. The 200-300 mesh silica gel was used for column purification. ${ }^{1} \mathrm{HNMR}$ and ${ }^{13} \mathrm{CNMR}$ spectra were recorded on Bruker Avance 400 spectrometer with TMS as internal standard. Splitting patterns are described as singlet $(\mathrm{s})$, doublet $(\mathrm{d})$, triplet $(\mathrm{t})$, quartet $(\mathrm{q})$, broad $(\mathrm{br})$, or doublet of doublet $(\mathrm{dd})$. The value of chemical shifts $(\delta)$ is given in ppm and coupling constants $(\mathrm{J})$ in Hertz $(\mathrm{Hz})$. Mass spectra were obtained using Agilent LC-MS instrument in electrospray positive and negative ionization modes. Starting materials used in the synthesis of the compounds of the invention include N-protected amino acids procured from chemical suppliers with purity not less than $99 \%$.

a-aminoacyl phenylalanine pinanediol boronic ester was prepared according to the known procedure.

*Corresponding author: Parimi Umadevi, Department of Chemistry, Institute of Science, GITAM University, Visakhapatanam-530045, Andhra Pradesh, India, Tel +91-9490753446; E-mail: umadevichemistry@gmail.com

Received May 21, 2014; Accepted August 20, 2014; Published August 22, 2014

Citation: Venugopal DVR, Yarla NS, Umadevi P (2014) Synthesis, of Novel Piperine Analogs of Dipeptidyl Boronic Acid as Antimicrobial and Anticancer Agents. Med chem 4: 606-610. doi:10.4172/2161-0444.1000201

Copyright: (c) 2014 Venugopal DVR, et al. This is an open-access article distributed under the terms of the Creative Commons Attribution License, which permits unrestricted use, distribution, and reproduction in any medium, provided the original author and source are credited. 
Extraction and Isolation of piperine: $200 \mathrm{~g}$ of ground black pepper powder was taken in a 1 liter round bottomed flask and $500 \mathrm{~mL}$ of $95 \%$ ethanol is added and refluxed for $2 \mathrm{~h}$. The mixture is filtered and concentrated by rotator evaporator $20 \mathrm{~mL}$ of $10 \%$ ethanolic $\mathrm{KOH}$ solution was added. The resulting solution is heated for ten minutes and water is added drop wise and further it was allowed to stand overnight. A yellow precipitate separated out. The solid precipitate is filtered and recrystallised with $10-20 \mathrm{~mL}$ of acetone to obtain $6 \mathrm{~g}$ of piperine.

Synthesis of Piperic acid from Piperine (Scheme-1): $5 \mathrm{~g}$ of Piperine $(17.5 \mathrm{mmol})$ is refluxed with methanolic $\mathrm{KOH}(2 \mathrm{~N}, 20 \mathrm{~mL})$ for $6 \mathrm{~h}$ and methanol was evaporated under reduced pressure, the solution was cooled in ice bath. The gummy potassium salt of piperic acid was suspended in water and gradually acidified with dil. $\mathrm{HCl}$; dark yellow precipitate was collected and stirred for 3-4 h in the cold ice bath, filtered and washed with cold water. The compound was recrystallised from methanol yielding yellow crystalline compound with $80 \%$ yield.

Synthesis of tetrahydro piperic acid (Scheme-1): To a solution of piperic acid (1 m.mol.) in ethanol, ammonium formate $(10 \mathrm{~m} . \mathrm{mol}$.) and $10 \% \mathrm{Pd} / \mathrm{C}(5 \mathrm{~mol} \%)$ were added, the mixture was stirred at 20 $25^{\circ} \mathrm{C}$ for $2 \mathrm{~h}$ and concentrated under vaccum. To the concentrated reaction mixture dichloromethane was added, the organic layer was washed with water, dried over anhydrous magnesium sulphate and concentrated to get tetrahydropiperic acid.

Synthesis of tetrabromo piperic acid (Scheme-1): $2 \mathrm{~m} . \mathrm{mol}$ of Bromine in dichloromethane is added to a solution of piperic acid (1 m.mol.) in $10 \mathrm{~mL}$ dichloromethane. The reaction mixture was stirred at $20-25^{\circ} \mathrm{C}$ until completion of the reaction. The solvent is evaporated under vacuum to get tetrabromopiperic acid.

General synthesis of piperine analogs of di peptidyl -boronic acid 1-3(Scheme-1)

\section{Stage 1: piperine analogs of peptidyl boronic ester}

To a solution (1 m.mol.) of piperic acid (for compound 1) or tetrahydro piperic acid (for compound 2) or tetrabromo piperic acid (for compound 3) in $20 \mathrm{~mL}$ of dry dichloromethane hydroxy benzotriazole (HOBt) $(0.6 \mathrm{~m} . \mathrm{mol}$.) and $\alpha$-aminoacyl phenylalanine pinanediol boronic ester $(1 \mathrm{~m} . \mathrm{mol}$.) were added. The contents were cooled to $0-5^{\circ} \mathrm{C}$, 1-Ethyl-3-(3-dimethyllaminopropyl) carbodiimide hydrochloride (EDC.HCl) (1 m.mol.) and N, N-diisopropylethylamine (DIPEA) ( $1 \mathrm{~m}$. mol.) were added. The reaction mixture was maintained at $20-25^{\circ} \mathrm{C}$ for completion. After completion of reaction the contents were washed with water $(10 \mathrm{~mL})$ followed by washing twice with aqueous solution of $1 \% \mathrm{H}_{3} \mathrm{PO}_{4}(10 \mathrm{~mL})$ and twice with aqueous solution of $2.5 \% \mathrm{~K}_{2} \mathrm{CO}_{3}(10 \mathrm{~mL})$. The resultant organic layer is concentrated under reduced pressure to get corresponding dipeptidyl boronic ester.

\section{Stage 2: piperine analogs of di peptidyl boronic acid}

The above obtained dipeptidyl boronic esters were dissolved in a mixture of $(10 \mathrm{~mL})$ methanol, $(10 \mathrm{~mL})$ hexane, isobutylboronic acid (1 m.mol.) followed by $(10 \mathrm{~mL}) 1 \mathrm{~N} \mathrm{HCl}(\mathrm{aq})$ solution and stirred at $25-30^{\circ} \mathrm{C}$ till the completion of the reaction. The aqueous layer was concentrated to remove methanol and was extracted with dichloromethane $(10 \mathrm{~mL})$ to get the product. The extracted compound was purified by column chromatography over silica gel (100-200 mesh) with DCM: Hexane mixture to get pure compounds 1-3.

The organic layer above obtained is purified to get the starting material isobutyl boronic acid pinanediol ester, to recycle the expensive (+) pinanediol completely.

Characterization of synthesized compounds: $\mathrm{Na}-[(2 E, 4 E)-$ 5 - ( 1,3 -benzodio/xol-5-yl) penta-2,4-dienoyl $]-N-\left[\left(\begin{array}{ll}1 & R\end{array}\right)-1\right.$ (dihydroxyboranyl) -3-methylbutyl]-L-phenylalaninamide (Compound 1): Yield: 80\%, ${ }^{1} \mathrm{H}-\mathrm{NMR}$ (400 MHz):7.2-7.4( $\left.4 \mathrm{H}, \mathrm{m}\right)$, $6.9(1 \mathrm{H}, \mathrm{s}), \quad 6.8(1 \mathrm{H}, \quad \mathrm{d}), \quad 6.78(2 \mathrm{H}, \mathrm{m}), \quad 6.6(1 \mathrm{H}, \mathrm{m}), \quad 6.4(1 \mathrm{H}, \quad$ brs $)$, 6.1 $(1 \mathrm{H}, \mathrm{brs}), \quad 5.97(2 \mathrm{H}, \mathrm{s}), \quad 5.93(1 \mathrm{H}, \mathrm{d}), \quad 4.7(1 \mathrm{H}, \mathrm{m}), \quad 4.28(1 \mathrm{H}, \mathrm{d}, \mathrm{j}=8.2$ $\mathrm{Hz}), \quad 3.32(3 \mathrm{H}, \mathrm{m}), \quad 2.35(1 \mathrm{H}, \mathrm{m}), \quad 2.2(1, \mathrm{~m}), \quad 2.03(1 \mathrm{H}, \mathrm{t}), \quad 1.7-2(4 \mathrm{H}, \mathrm{m})$, 1.4-1.6(2H,m)1.37(2H,m), $1.2(2 \mathrm{H}, \mathrm{m}), \quad 1.25(2 \mathrm{H}, \mathrm{m}), \quad 1.1-1.2(2 \mathrm{H}, \mathrm{m})$, $0.97(6 \mathrm{H}, \mathrm{t})$.<smiles>[R]C(C(=O)O)C([R])C([R])C([R])c1ccc2c(c1)OC(C)C21COc2cc(/C=C/C=C/C(=O)O)ccc2O1</smiles>

(b)<smiles>CC(C)C[C@H](NC(=O)C(Cc1ccccc1)NC(=O)/C=C/C=C/c1ccc2c(c1)OCO2)B1OC2CC3CC1(C)[C@](C)(C3)C2</smiles>

(c)<smiles>CC(C)C[C@H](NC(=O)C(Cc1ccccc1)NC(=O)/C=C/C=C/c1ccc2c(c1)OCO2)B(O)O</smiles>

(b)

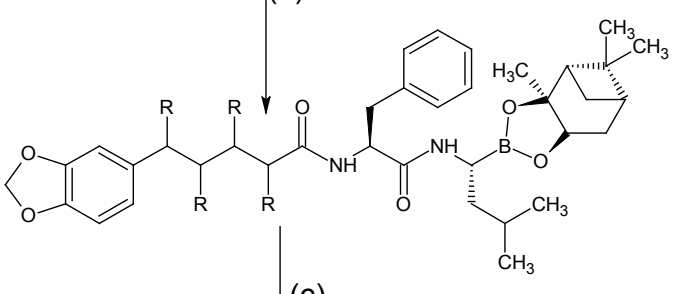

(c)

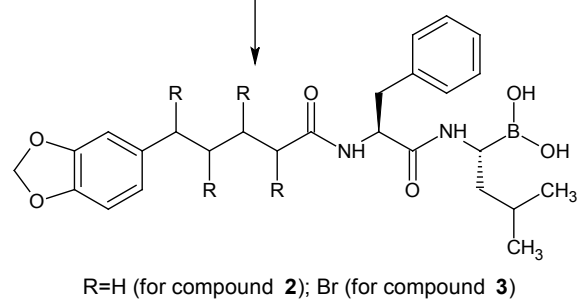

Reagents: (a) KOH / Heating; (b) $\alpha$-aminoacyl phenylalanine pinanediol boronic ester, EDC. $\mathrm{HCl}, \mathrm{HOBt} ;(\mathrm{c}) \mathrm{MeOH}, 1 \mathrm{NHCl}$ 
${ }^{13}$ C-NMR (400 MHz): 173.48 (C=O), $167.56(\mathrm{C}=\mathrm{O}), 148.1,141.54$, $138.35(\mathrm{CH}=\mathrm{CH}), 129.52,128.3,128.97,108.34,101.17\left(\mathrm{O}-\mathrm{CH}_{2}-\mathrm{O}\right)$, $56.01(\mathrm{~N}-\mathrm{C}-\mathrm{C}=\mathrm{O}), 53.2(\mathrm{C}-\mathrm{B}), 39.94\left(-\mathrm{CH}_{2}-\mathrm{Ph}\right), 27.14,22.9\left(-\mathrm{CH}_{3}\right) \cdot \mathbf{M} / \mathbf{z}$ : 478.3

$N a-[5-(1,3-b e n z o d i o x o l-5-y l)$ pentanoyl] $-N-[(1 R)-1$ (dihydroxyboranyl)-3-methylbutyl]-L-phenylalaninamide (Compound 2): Yield: 78\%, ${ }^{1} \mathrm{H}-\mathrm{NMR}$ (400 MHz): 7.17 (1H, m), 7.07 $(2 \mathrm{H}, \mathrm{m}), 6.93(2 \mathrm{H}, \mathrm{m}), 6.7(3 \mathrm{H}, \mathrm{m}), 5.91(2 \mathrm{H}, \mathrm{m}), 5.5(2 \mathrm{H}, \mathrm{brs}), 4.6(1 \mathrm{H}, \mathrm{m})$, 3.65 $(1 \mathrm{H}, \mathrm{m}), 3.07(2 \mathrm{H}, \mathrm{m}), 2.54(2 \mathrm{H}, \mathrm{t}), 2.2(2 \mathrm{H}, \mathrm{t}, \mathrm{j}=8 \mathrm{~Hz}), 1.82(1 \mathrm{H}, \mathrm{m})$, 1.7 $(2 \mathrm{H}, \mathrm{m}), 1.64(2 \mathrm{H}, \mathrm{m}), 1.24(1 \mathrm{H}, \mathrm{m}), 1.44(1 \mathrm{H}, \mathrm{m}), 0.9(6 \mathrm{H}, \mathrm{t}) .{ }^{13} \mathrm{C}-\mathrm{NMR}$ (400 MHz): 173(C=O), 148.1, 146.1, 137.4, 136.8, 129.21, 128.6, 128.2, $121.1,108.8,108.1,100.68\left(\mathrm{O}-\mathrm{CH}_{2}-\mathrm{O}\right), 54.26,52.84,39.94,38.36,36.55$, 34.47, 29.84, 27.14, 25.09, 22.9. M/z: 482.3

$\mathrm{Na}$-[5-(1,3-benzodioxol-5-yl)-2,3,4,5-tetrabromopentanoyl]- $\mathrm{N}$ [(1R)-1-(dihydroxyboranyl)-3-methylbutyl]-L-phenylalaninamide (Compound 3): Yield: 66\%, ${ }^{1} \mathrm{H}-\mathrm{NMR}(400 \mathrm{MHz}): 7.2(1 \mathrm{H}, \mathrm{m})$, 7.15 $(1 \mathrm{H}, \mathrm{m}), 7.09(1 \mathrm{H}, \mathrm{m}), 7.07(1 \mathrm{H}, \mathrm{m}), 6.93(1 \mathrm{H}, \mathrm{m}), 6.88(1 \mathrm{H}, \mathrm{m})$, 6.6 $(1 \mathrm{H}$, brs $), 6.48(1 \mathrm{H}, \mathrm{brs}), 5.9(2 \mathrm{H}, \mathrm{s}), 5.44(1 \mathrm{H}, \mathrm{d}, \mathrm{j}=8 \mathrm{~Hz}), 5.24(1 \mathrm{H}$, dd), 5.02(1H, brs), 5.04(1H, d, j=12 Hz), 4.9(1H, dd), 4.7 $(1 \mathrm{H}, \mathrm{m})$, 3.64 $(1 \mathrm{H}, \mathrm{m}), 3.1(2 \mathrm{H}, \mathrm{m}), 1.82(1 \mathrm{H}, \mathrm{m}), 1.45(1 \mathrm{H}, \mathrm{m}), 1.25(1 \mathrm{H}, \mathrm{m})$, 0.9(6H,s). ${ }^{13}$ C-NMR (400 MHz): $172.56(\mathrm{C}=\mathrm{O}), 165.38(\mathrm{C}=\mathrm{O}), 149.18$ (Aromatic), 147.07, 136.57, 130.58, 129.3, 128.6, 128.2, 122.64, 109.29, 108.02, 101.13, 59.02, 56.13, 55.8 (CH-Br), 53.2, 52.8 (CH-B), 49.1, 39.3, 38.1 ( $\left.\mathrm{CH}_{2}-\mathrm{Ph}\right), 27.1,22.9(\mathrm{CH} 3) ; \mathbf{M} / \mathbf{z :}$ 797.4.

\section{Bioactivity Studies}

\section{In vitro anticancer studies}

Cell lines and Cell Culture: Carcinoma of the cervix (HeLa) cells, MCF-7 breast and MIA PaCa-2 pancreatic cancer cells were maintained in Dulbecco's modified essential medium (DMEM) supplemented with $4.5 \mathrm{~g} / \mathrm{L}$ glucose, $2 \mathrm{mM}$ L-glutamine and $5 \%$ fetal bovine serum (FBS) (growth medium) at $37^{\circ} \mathrm{C}$ in $5 \% \mathrm{CO}_{2}$ incubator.

MTT assay: The MTT assay developed by Mosmann was modified and used to determine the inhibitory effects of test compounds on cell growth in vitro. In brief, the trypsinized cells from T-25 flask were seeded in each well of 96-well flat-bottomed tissue culture plate at a density of $5 \times 10^{3}$ cells/well in growth medium and cultured at $37^{\circ} \mathrm{C}$ in $5 \% \mathrm{CO}_{2}$ to adhere. After $48 \mathrm{~h}$ incubation, the supernatant was discarded and the cells were pretreated with growth medium and were subsequently mixed with different concentrations of test compounds $(32,64,128,256$ and $500 \mu \mathrm{g} / \mathrm{mL})$ in triplicates to achieve a final volume of $100 \mu \mathrm{L}$ and then cultured for $48 \mathrm{~h}$. The compound was prepared as $1.0 \mathrm{mg} / \mathrm{mL}$ concentration stock solutions in PBS. Culture medium and solvent are used as controls. Each well then received $5 \mu \mathrm{L}$ of fresh MTT (3-(4,5-dimethylthiazol-2-yl)-2,5-diphenyltetrazolium bromide) 0.5 $\mathrm{mg} / \mathrm{mL}$ in PBS followed by incubation for $2 \mathrm{~h}$ at $37^{\circ} \mathrm{C}$. The supernatant growth medium was removed from the wells and replaced with 100 $\mu \mathrm{L}$ of DMSO to solubilize the colored Formosan product. After 30 min incubation, the absorbance (Optical Density) of the culture plate was read at a wavelength of $570 \mathrm{~nm}$ on an ELISA reader, Anthos 2020 spectrophotometer. The $\mathrm{IC}_{50}$ values are calculated and the results are tabulated in Table 1

Determination of Antibacterial activity: One hundred micro liters suspension containing $10^{8} \mathrm{CFU} / \mathrm{mL}$ of bacteria was inoculated on the surface of Muller-Hinton agar medium (MHA) plates. The compound dissolved in 2\% DMSO served as negative control and Ampicillin was used as a standard reference to determine the sensitivity of each microbial species tested for antibacterial. The Minimum Inhibitory Concentrations (MIC) of the compounds were estimated as per the guidelines of clinical laboratory standard. Bacterial suspensions were prepared by suspending the cultures grown for $24 \mathrm{~h}$ in sterile normal saline. The turbidity of the bacterial suspension was adjusted to McFar land standard of 0.5 which is equivalent to $1.5 \times 10^{8} \mathrm{CFU} / \mathrm{mL}$. Two fold serial dilution of each compound was prepared in MHA. The MIC of the compounds (1-3) ranged between $(50-500 \mu \mathrm{g} / \mathrm{mL})$. The antimicrobial activities of the synthesized compounds were tested against Escherichia coli, Klebsiella pneumoniae, Pseudomonas Aeruginosa, Bacillus subtilis, Salmonella typhi, Shiegella dysenteriae, Staphylococcus Aureus. The results are shown in Table 2

Minimum Inhibitory Concentration (MIC): MIC was determined by serial dilution method. Two fold serial dilutions of test compounds were carried out in nutrient broth. To each test tube $10^{5} \mathrm{CFU} / \mathrm{mL}$ of active bacterial cultures were inoculated. Piperine was used as reference drug. The culture tubes were incubated at $37^{\circ} \mathrm{C}$ for $24 \mathrm{~h}$. After the incubation the tubes were checked for bacterial growth and the MIC was determined and expressed in $\mathrm{mg} / \mathrm{mL}$.

Antifungal screening: Sterile 96-well polystyrene microtitre plates with well capacities of $300 \mu \mathrm{L}$ were used and $100 \mu \mathrm{L}$ of fresh Mueller Hinton broth were added to each well of the plate. One hundred microlitres of the compound stock solution were added to each well of the first column. Then, $100 \mu \mathrm{L}$ of the solution were removed from the first column and mixed thoroughly with the broth in the corresponding wells of the second column. Subsequently, a $100 \mu \mathrm{L}$ aliquot was removed from each well in this column and mixed with contents of the corresponding well of the next column. This doubling dilution was performed in all rows across the plate. One row was used as a positive control and contained an antimycotics nystatin and fluconazole to determine the sensitivity of fungal species. The other row contained the solvent (DMSO) as a negative control. In each well of the plate $10 \mu \mathrm{L}$ of fungi cultures $\left(10^{5}\right.$ spores per $\left.\mathrm{mL}\right)$ were inoculated. The microtitre plate was incubated at $37^{\circ} \mathrm{C}$ for $48 \mathrm{~h}$ for fungi. After that, fungi growths were measured. The MIC was determinate as the lowest concentration that resulted in inhibition of fungal growth. The results are tabulated in Table 3

Docking and comparison with the experimental data: The $3 \mathrm{D}$ Crystal structure of ligand free yeast $20 \mathrm{~S}$ proteasome (PDB id: 3BDM), ligand free Thermus thermophiles Leucyl-tRNA synthase (PDB id: 2BTE) were obtained from RCSB, PDB database (www.rcsb.org). The protein is validated using Procheck and what if sever. The core structures of all ligands were predicted and sketched using ISIS draw

\begin{tabular}{|c|c|c|c|}
\hline Compound & Breast cancer & Cervical cancer & pancreatic cancer \\
\hline 1 & $64 \pm 0.5$ & $33 \pm 0.3$ & $31 \pm 0.3$ \\
\hline 2 & $104 \pm 0.2$ & $48 \pm 0.1$ & $53 \pm 0.4$ \\
\hline 3 & $201 \pm 0.3$ & $256 \pm 0.2$ & $301 \pm 0.6$ \\
\hline Piperine & $99 \pm 0.2$ & $69 \pm 0.3$ & $110 \pm 0.5$ \\
\hline
\end{tabular}

Table 1: Determination of Anticancer activity $\mathrm{IC}_{50}{ }^{*}$ in $\mu \mathrm{M}$.

\begin{tabular}{|c|c|c|c|c|c|c|c|c|c|c|}
\hline Compound & S.aureus & S.pyogenes & E.coli & C.koseri & K.oxytoca & K.pneumoniae & S.dysentriae & S.typhi & C.fruendi & P.aeruginosa \\
\hline 1 & 2.5 & 2.5 & 0.6 & 1.25 & 0.6 & 0.6 & 0.6 & 1.25 & 2.5 & 2.5 \\
\hline 2 & 2.5 & 2.5 & 0.6 & 1.25 & 0.6 & 0.6 & 0.25 & 2.5 & 1.25 & 2.5 \\
\hline 3 & 1.25 & 0.6 & 0.6 & 0.25 & 0.25 & 0.25 & 0.6 & 0.25 & 0.6 & 1.25 \\
\hline Piperine & 1.25 & 1.25 & 0.3 & 0.9 & 0.4 & 0.2 & 0.6 & 1.25 & 1.25 & 1.25 \\
\hline
\end{tabular}




\begin{tabular}{|c|c|c|c|c|c|}
\hline Compound & $\begin{array}{c}\text { Asperigillus } \\
\text { flavus }\end{array}$ & $\begin{array}{c}\text { Asperigillus } \\
\text { fumigatus }\end{array}$ & $\begin{array}{c}\text { Asperigillus } \\
\text { niger }\end{array}$ & $\begin{array}{c}\text { Pencillium } \\
\text { spp }\end{array}$ & $\begin{array}{c}\text { Candida } \\
\text { albicans } \\
\text { (5 Isolates) }\end{array}$ \\
\hline 1 & 0.6 & 2.5 & 1.25 & 0.6 & $0.25-1$ \\
\hline 2 & 0.12 & 0.25 & 0.12 & 0.25 & $0.31-1.25$ \\
\hline 3 & 0.25 & 1.2 & 0.5 & 0.25 & $0.25-1$ \\
\hline Piperine & 0.3 & 0.6 & 0.6 & 0.6 & $0.5-1$ \\
\hline
\end{tabular}

Table 3: Determination of Antifungal Activity (MIC mg/ml).

software. They were geometrically optimized and energy minimized on to 3D structure using Dundee PRODRG-2 server and retrieved in PDB format for docking. The docking studies of all the synthesized compounds were carried out in Molegro Virtual Docker.

Protein-ligand interactions were carried out in Molegro virtual docker. The missing bond orders, hybridization and charges were assigned to the protein which is implemented in the program itself. Potential binding sites were detected using cavity detection algorithm and docking was performed.. The cavity docking procedure was carried with an energy grid resolution of $0.30 \mathrm{~A}^{\circ}$ taking the default parameters. The algorithm Mol Dock SE includes total number of runs as 10, population size of 50 and the Maximum Interactions -1500. The output was visualized in Molegro Virtual docker as per Figures 1 to 3.

We have docked different sets of piperine-dipeptidyl boronic acid analogs. Based on the primary model with compound 1 we have designed the analogs. The results are tabulated in Table 4.

\section{Results and Discussion}

\section{Chemistry}

Piperine was extracted from the dried seeds of piper nigrum, converted into acid by hydrolysis using ethanolic- $\mathrm{KOH}$ and con.HCl. The acid is condensed with amine group of $\alpha$-aminoacyl phenylalanine pinanediol boronic acid in dichloromethane with EDC.HCl (1-Ethyl3-(3-dimethylaminopropyl) carbodiimide. $\mathrm{HCl}$ ). $\mathrm{EDC} . \mathrm{HCl}$ was chosen as coupling agent because of its selectivity, and the water soluble byproduct, which can be washed away to administer the pure product. The piperidine amide of natural piperine was replaced with a-aminoacyl phenylalanine boronic acid to get compounds (1-3). All the tested compounds (1-3) were characterized by ${ }^{1} \mathrm{H},{ }^{13} \mathrm{C}$ NMR and LC-MS analysis. IR spectrum of the compounds showed absorption at 1578$1657 \mathrm{~cm}^{-1}$ due to amide bond $\mathrm{C}=\mathrm{O}$ stretching frequency; the ${ }^{1} \mathrm{H}-\mathrm{NMR}$ values of $\delta 2.97-\delta 3.58$ is due to $(-\mathrm{HC}-\mathrm{B})$ the value at $\delta 4.91-\delta 5.1$ in dipeptidyl boronic acids is due to $(-\mathrm{N}-\mathrm{CH}-\mathrm{CO})$.

\section{Biological activity}

The cytotoxic activity was carried out by MTT (3-(4,5-dimethylthiazol-2-yl)-2,5-diphenyltetrazolium bromide) assay and results were presented in Table 1. Compound 1, piperine analog of dipeptidyl boronic acid was superior to the other two compounds with an $\mathrm{IC}_{50}$ as low as $31+0.3 \mu \mathrm{M}$ against pancreatic cancer cell line.

The antibacterial assay was carried out by the consecutive dilution method and the MIC values were recorded and abbreviated in Table 2. Among the entire tested compounds, compound 3 containing tetrabromo piperic acid was found to be best antibacterial against K.pneumoniae. The MIC values of all most all the tested compounds were comparable to piperine.

To actuate the antifungal activity of these compounds, we screened for their minimum inhibitory concentration (MIC) against a wide array of fungal strains (Table 3). Our initial lead was Piperine analog of dipeptidyl boronic acid (1) showed a modest activity against Asperigillus fumigates. To increase its activity the lead was reduced to get tetrahydro derivative (2), and brominated to get tetrabromo derivative (3). Compound 2 showed lowest MIC value means good antifungal activity.

The docking studies of all the synthesized compounds were agitated out in Molegro virtual docker and the binding energies are represented in Table 4. The structures of the docked compounds were represented in Figures 1 to 3, with receptor ligand interactions. After antecedent screening the compounds with a higher docking score than piperine were synthesized.

\section{Discussion}

A total of three piperine analogs of dipeptidyl-boronic acid were synthesised and subjected to docking analysis. The compounds were evaluated for anti microbial and anti neoplastic activity. The anti-

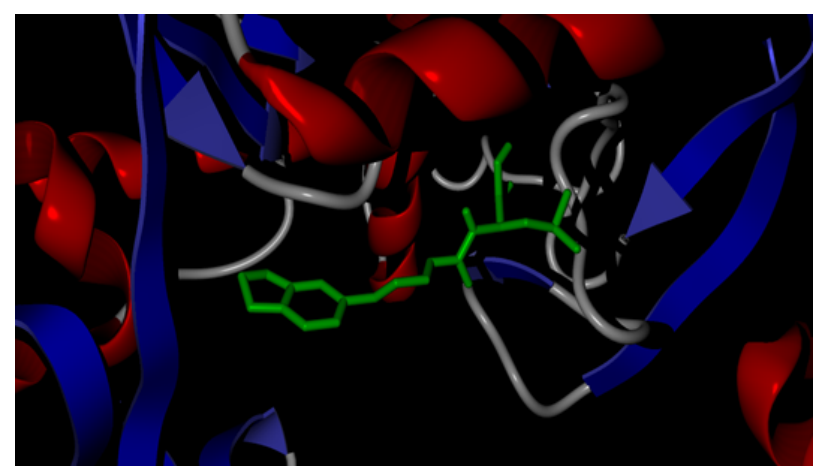

Figure 1: Interaction of compound1 with protein 2BTE; protein shown in backbone structure and ligand in green color.

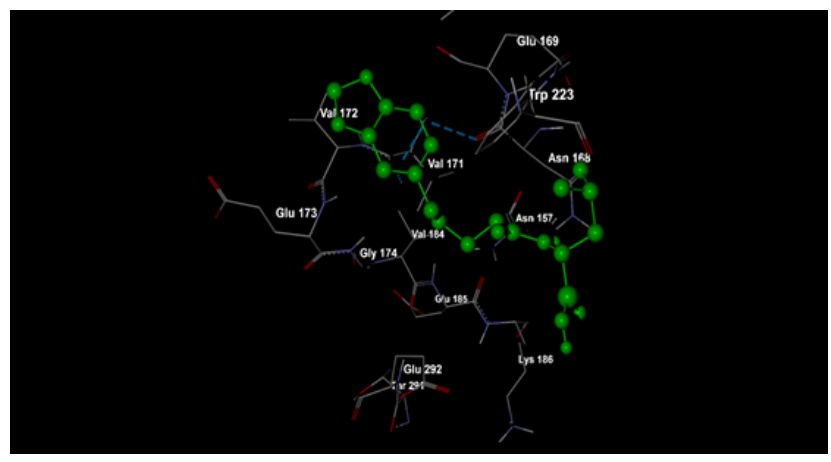

Figure 2: Interactions of Compound 2 with protein in wireframe form with hydrogen bondings in blue color.

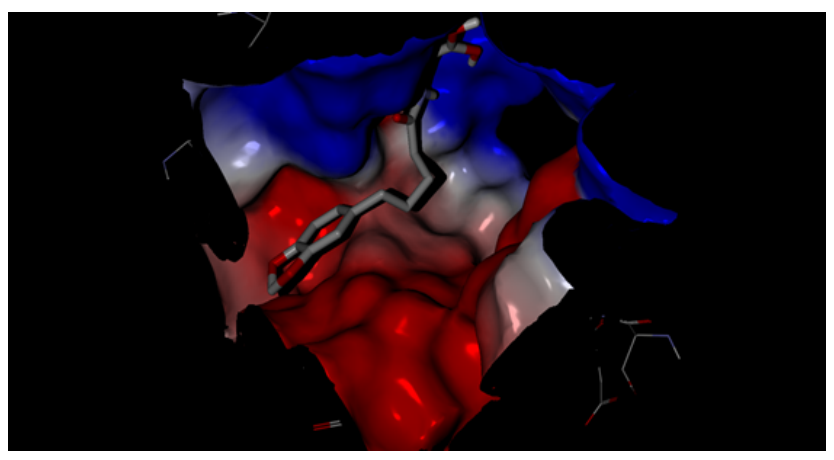

Figure 3: Electrostatic interaction of compound 2 with protein. 


\begin{tabular}{|c|c|c|}
\hline \multirow{3}{*}{ Dock Score (Kcal/mol) } \\
\hline \multirow{2}{*}{ Compound } & Leucyl t-RNA synthase & Yeast 20S proteasome \\
\cline { 2 - 3 } & (2BTE) & (3BDM) \\
\hline 1 & -99.98 & -180.9 \\
\hline 2 & -115.96 & -164.65 \\
\hline 3 & -98.47 & -166.56 \\
\hline Piperine & -88.9 & -109.51 \\
\hline $\begin{array}{c}\text { a-aminoacyl phenylalanine } \\
\text { pinanediol boronic ester }\end{array}$ & -101.5 & -121.9 \\
\hline
\end{tabular}

Table 4: Determination of Moldock scores of Piperine-boronic acid analogs on proteins Dock.

neoplastic activity of Piperine analog of dipeptidyl-boronic acid (compound-1) was best among all the tested compounds. The antimicrobial activity of compound-2 containing tetrabormopipericacid nucleus was found to be best against K.pneumoniae. The insilico results are in concordance with invitro results.

\section{Conclusions}

A total of three piperine dipeptidyl-boronic acid conjugates were designed and synthesized. They were subjected to molecular docking to estimate their binding efficiency. All the synthesized compounds possess antimicrobial as well as antineoplastic properties. However, the presence of halogen as hetero atom enhanced the ligand protein binding interaction among the synthesized piperine-boronic acid conjugates. In silico studies are in concordance with in vitro studies. Compound 3, that apparently accomplished higher binding affinity showed the lowest MIC values for all the tested organisms ( MIC ranging from 0.25-2.5 $\mu \mathrm{g} / \mathrm{mL}$ ). We also found that reduction of the double bonds in piperine resulted in lower anticancer activity; bromination of the double bonds further decreased the anticancer activity in contrast we found that the reduction of double bonds or bromination of double bonds enhanced the antimicrobial activity. We conclude analogs of piperine-dipeptidyl boronic acids were superior to piperine with respect to both cytotoxic and antimicrobial properties which paves a way for the synthesis of novel therapeutics.

\section{References}

1. Frankland E, Duppa BF, Justus (1860) VorläufigeNotizüberBoräthyl. liebigs Ann Chem 115: 319-322.

2. Sangwan PL, Koul JL, Koul S, Reddy MV, Thota N, et al. (2008) Piperine analogs as potent Staphylococcus aureus NorA efflux pump inhibitors. Bioorg Med Chem 16: 9847-9857.

3. Mujumdar AM, Dhuley JN, Deshmukh VK, Raman PH, Naik SR (1990) Antiinflammatory activity of piperine. Jpn J Med Sci Biol 43: 95-100.

4. Mittal R, Gupta RL (2000) In vitro antioxidant activity of piperine. Methods Find Exp Clin Pharmacol 22: 271-274.

5. Matsuda H, Ninomiya K, Morikawa T, Yasuda D, Yamaguchi I, et al. (2009) Hepatoprotective amide constituents from the fruit of Piper chaba: Structural requirements, mode of action, and new amides. Bioorg Med Chem 17: 73137323.

6. Umesh K Patil, Amritsingh, Anup K Chakraborty (2011) International Journal of Recent Advances in Pharmaceutical Research 4: 16.

7. Szepietowski JC, Salomon J (2007) Do fungi play a role in psoriatic nails? Mycoses 50: 437-442.

8. Baran R, Faergemann J, Hay RJ (2007) Superficial white onychomycosis-a syndrome with different fungal causes and paths of infection. J Am AcadDermatol 57: 879-882

9. Kumar satish, Durvasulavenugopalvenkatarama, rathodparendudhirajlal (Ranbaxy laboratories limited), WO 0989632011.

10. Methods for antimicrobial susceptibility testing of anaerobic bacteria, fifth Edition, Approved standard M11-A5, 2001. 